Research Square
Preprints are preliminary reports that have not undergone peer review.

They should not be considered conclusive, used to inform clinical practice, or referenced by the media as validated information.

\title{
Spatial Occurrence and Sources of Polycyclic Aromatic Hydrocarbons in Sediments Drive the Ecological Risk of Taihu Lake, China
}

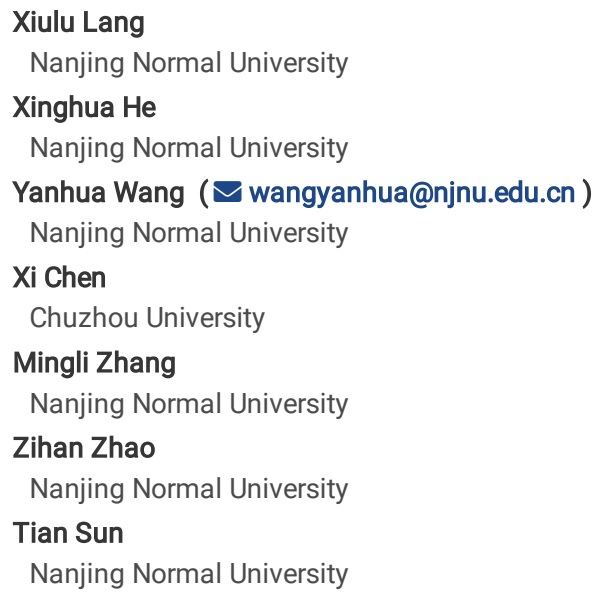




\section{Abstract}

To study the spatial occurrence, sources, and ecological risks of $16 \mathrm{PAHs}$, surface sediments had been collected from seven major areas of Taihu Lake, China in April 2021. Results showed that the concentrations of $\sum_{16}$ PAHs varied between 1381.48 4682.16 ng g ${ }^{-1}$, and the contents of BghiP in each sample were the highest. The PAHs concentrations in the sediments near the lakeshore were much higher than those in the central area of the lake. The sedimentary $\sum_{16} \mathrm{PAHs}$ were mainly composed of molecular-weight monomers and 4-ring PAHs showed superiority (35.69\% 45.02\%). According to the ratio of PAH monomer, the sedimentary PAHs in Taihu Lake were dominantly derived from the combustion. Through the biological toxicity assessment and the BaP equivalent (BaPE), great biological risks of PAHs monomers i.e. DahA and IcdP were found. Both concentrations of $\sum_{16} \mathrm{PAHs}$ and dominant $4 \sim 6$-ring monomers accompanied by carcinogenic risks in many areas of Taihu Lake increased. It is necessary to strengthen monitoring and take measures to control the input of organic pollutants.

\section{Introduction}

Polycyclic aromatic hydrocarbons (PAHs) are typical persistent organic pollutants, which have mutagens, carcinogens, teratogens, and gene toxins, and exist in different environmental media for a long time ${ }^{1-3}$. PAHs could be accumulated through atmospheric deposition, growth of surface vegetation in soil and plants, and then enter the aquatic environment through surface runoff, thereby affecting water ecological security and food chain transmission ${ }^{4}$. Besides, PAHs in the aquatic environment may be derived from fuels, incomplete combustion, bioorganic metabolism, and the transformation process in sediment ${ }^{5}$. Among them, fuels and incomplete combustion were anthropogenic-driven, an important contributor to PAHs pollution in aquatic ecosystems.

Sediment, as a repository of PAHs, plays an important role in environmental information archives ${ }^{6-9}$. Due to the rapid social-economical development and the widespread use of fossil fuels, the deposition flux of PAHs showed an increasing trend year by year ${ }^{10}$. The global total PAHs emissions in 2004 were $520 \mathrm{Gg}$, and China contributed the most (21.9\%), with a high proportion of high-ring PAHs ${ }^{11}$. With the development of China's economy, PAHs emissions are increasing. More than $50 \%$ of the discharged PAHs entered the water environment.

Taihu Lake, located on the southern edge of the Yangtze River Delta, is the third-largest freshwater lake in China. The Taihu Lake Basin is densely populated, and its economy and industry are also relatively developed ${ }^{12}$. Whether the concentration of PAHs in the Taihu Lake Basin exceeded the standard and whether it posed a health threat to the surrounding population had received widespread attention ${ }^{13-15}$. Since 2000 , the concentration of PAHs in the sediments of the Taihu Lake Basin had ranged between $698.00 \sim 962.00 \mathrm{ng} \mathrm{g}^{-1}$, after $209.00 \sim 3842.00 \mathrm{ng} \mathrm{g}^{-1}$ in 2010, and gradually changed to $4900.00 \sim 16800.00 \mathrm{ng} \mathrm{g}^{-1}$ in $2021^{16-18}$, showing a continuous upward trend. To investigate the annual occurrence and source changes of PAHs in Taihu Lake sediments is urgent. The aims of this study were to 1) quantify 16 PAHs in the sediments of different lake areas in Taihu Lake by gas chromatography-mass spectrometry (GC-MS), 2) explore the occurrence and origins of PAHs in sediments of various-type zones; 3 ) assess the potential ecological and carcinogenic risks of different PAHs species in Taihu Lake.

\section{Materials And Methods Study site and samples collection}

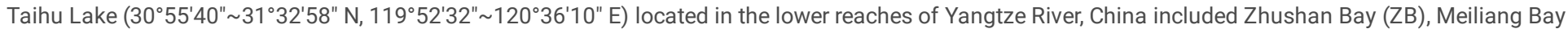
(MB), Gonghu Bay (GB), East Taihu area (ETA), South Taihu area (STA), West Taihu area (WTA) and Lake Center (LC). Fifty-two surface sediment samples (Z1 Z6, M1 M11, G1 G6, E1 E11, S1 S4, W1 W4, C1 C10) in above different lake areas of Taihu Lake were sampled through the grab bucket in April 2021 (Fig. 1). The samples were collected into sealed polyethylene bags sterilized by ethylene oxide (Nasco, USA) and placed in an incubator covered with ice packs. The latitudes and longitudes of the sampling locations were obtained through a handheld GPS device (Jiaming, eTrex 221x). After that, the samples were transported to the laboratory and stored in a refrigerator at $4^{\circ} \mathrm{C}$ for further analysis.

\section{Extraction methods of organic materials}

After vacuum freeze-drying, the shellfish and large plant roots in the sediment were removed, the samples were ground with an agate mortar and then sieved with a standard 100-mesh sieve (particle size $<0.15 \mathrm{~mm}$ ).

Approximately $(2 \pm 0.0001) \mathrm{g}$ of the freeze-dried sample was transferred into a $34-\mathrm{mL}$ extraction cell that had been pre-covered with a gasket and well mixed. Using $n$-hexane/dichloromethane solution (1:1, v:v) as the solvent, the mixed sample was put into the accelerated solvent extractor (ASE) with a 350 system (Thermo Scientific, USA). The reaction condition in the system was set as follows: heating at $100^{\circ} \mathrm{C}$ for 5 min and extracting at $1500 \mathrm{psi}(10 \mathrm{MPa})$ for $5 \mathrm{~min}$. $\mathrm{N}_{2}$ purge was applied for $90 \mathrm{~s}$ to collect the extract in the collection bottle. The extract was transferred to a round bottom flask and concentrated to $2 \mathrm{~mL}$ by a vacuum rotary evaporator in a $40^{\circ} \mathrm{C}$ water bath. Anhydrous sodium sulfate and silica gel were activated at $450^{\circ} \mathrm{C}$ and $180^{\circ} \mathrm{C}$ for $4 \mathrm{~h}$ and $6 \mathrm{~h}$, respectively. After cooling to room temperature, a chromatographic column was successfully prepared by filling $1.5 \mathrm{~g}$ of anhydrous sodium sulfate, $1 \mathrm{~g}$ of silica gel, and $1.5 \mathrm{~g}$ of anhydrous sodium sulfate from top to bottom. Subsequently, the extract was transferred to the prepared chromatographic column and washed with $15 \mathrm{~mL}$ of $n$-hexane/dichloromethane mixture (1:1, v:v) and $5 \mathrm{~mL}$ of $n$-hexane, and the rinsing fluid was collected to the corresponding flask. The collected liquid was evaporated to $0.5 \mathrm{~mL}$ by the rotary evaporator again. The residual collection liquid in the flask was rinsed with $n$-hexane, and the final volume was adjusted to $1 \mathrm{~mL}^{19-21}$.

\section{Determination of PAHs concentration and composition}


In a GC-MS system (Agilent 8860-5977, USA), the pretreated sample was analyzed after passing through a B-5MS $(0.25-\mu \mathrm{m}$ film thickness, $30 \mathrm{~m} \times 0.25 \mathrm{~mm}$

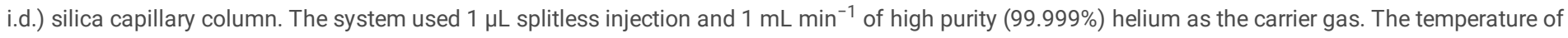
the injector was $250^{\circ} \mathrm{C}$ while the detector was $280^{\circ} \mathrm{C}$. The system procedure was as follows: hold at $50^{\circ} \mathrm{C}$ for $1 \mathrm{~min}$, to $180^{\circ} \mathrm{C}$ at $15^{\circ} \mathrm{C}$ min ${ }^{-1}$, then to $280^{\circ} \mathrm{C}$ at $5^{\circ} \mathrm{C} \mathrm{min}{ }^{-1}$, and hold for $5 \mathrm{~min}$. The mass detector was maintained at $70 \mathrm{eV}$ and the ion source temperature was $280^{\circ} \mathrm{C}$. $16 \mathrm{PAHs}$ were measured in full scan mode (50 550 amu).

\section{Assessment of PAHs pollution level}

The ecological risk assessment of PAHs in sediments was frequently carried out using effects range-low (ERL) and effects range-median (ERM) 22,23 . According to the evaluation criteria, when the concentration of PAHs was lower than the concentration of ERL, there was no adverse effect of the PAHS in the area; while the concentration of PAHs was higher than the concentration of ERM, it indicated that the regional PAHs was harmful to the biological community 24,25 .

The carcinogenic potential of PAHs was appraised through the equivalent of Benzo(a)pyrene (BaPE) ${ }^{26}$. The value of BaPE was calculated by the concentrations weighted of PAH with the carcinogenic potential of individual PAHs (Ji et al. 2007). The calculation formula of BaPE was shown in EQ. (1).

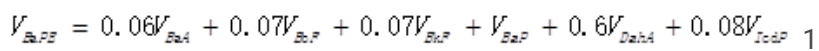

where $V$ represents the value of BaPE; BaA, BbF, BkF, BaP, DahA and IcdP mean Benzo(a)anthracene, Benzo(b)fluoranthene, Benzo(k)fluoranthene, Benzo(a)pyrene, Dibenzo(a,h)anthracene and Indeno(1,2,3-cd)pyrene, respectively.

\section{Quality control and quality assurance}

All glass containers involved in the experiment were baked at $500^{\circ} \mathrm{C}$ for $4 \mathrm{~h}$ in advance. A seven-point calibration curve $(50,100,250,500,1000,2000$, and $\left.2500 \mathrm{ng} \mathrm{mL}^{-1}\right)$ with correlation coefficients $\left(r^{2}>0.996\right)$ was selected in combination with an external standard method to quantify PAHs. No target compound was detected in the method blanks The average recovery rates of PAHs were $>75 \%$ in all samples, and the obtained concentration does not pass the recovery rate correction. In repeated samples, the relative standard deviations of PAHs were less than $10 \%$. This study was based on the dry weight of surface sediments samples.

\section{Statistical analysis}

All statistical data were conducted using the statistical procedures SPSS 21.0 (SPSS Inc. Chicago, USA). The probable origin of the PAHs, including pyrogenic or petrogenic was determined, the following isomeric relationships were calculated: Ant/(Ant+Phe), Flua/(Flua+Pyr), and IcdP/(IcdP+BghiP). Principal component analysis (PCA) was applied to perform dimensionality reduction processing analysis on the original data. The correlation coefficients between the variables were combined into fewer factors, through the correlation between factors to determine the pollution source of PAHs in sediments.

\section{Results And Discussion}

\section{Spatial characteristics of PAHs concentration in surface sediments}

The total and individual concentrations of PAHs in surface sediments collected from the different locations of Taihu Lake were shown in Table 1. 16 kinds of PAH were detected in the surface sediments of Lake Taihu in this study, with concentrations ranging between 1381.48 4682.16 ng $\mathrm{g}^{-1}$. There were obvious differences in the concentration of 16 PAHs. The values of DahA and IcdP were below the detection limit in some samples, while the concentrations of BghiP in each sample were higher. Ace had the lowest contents in each sample. The concentrations of PAHs in ZB were higher than those in other regions, and the concentrations of pollutants in the central area of the lake were the lowest. Compared with those in 2000 and 2010, the concentrations of PAHs had a clear upward trend ${ }^{16,17}$. 
Table 1

The concentration of PAHs at different sampling points in Taihu Lake

\begin{tabular}{|c|c|c|c|c|c|c|c|c|c|c|c|c|c|c|c|c|}
\hline \multicolumn{2}{|c|}{$\begin{array}{l}\text { Sample } \\
\text { points }\end{array}$} & Nap & Acy & Ace & Flu & Phe & Ant & Flua & Pyr & $\mathrm{BaA}$ & Chry & $\mathrm{BbF}$ & BkF & $\mathrm{BaP}$ & DahA & IC \\
\hline \multicolumn{2}{|l|}{ Rings } & 2 & 3 & 3 & 3 & 3 & 3 & 4 & 4 & 4 & 4 & 5 & 5 & 5 & 5 & 6 \\
\hline & & \multicolumn{15}{|c|}{$\mathrm{ng} \mathrm{g}^{-1}$ (dry weight) } \\
\hline \multirow[t]{10}{*}{ LC } & $\mathrm{C} 1$ & 9.01 & 26.16 & 7.02 & 53.60 & 100.23 & 120.97 & 171.92 & 174.31 & 271.24 & 208.48 & 271.96 & 313.52 & 161.60 & ND & $\mathrm{N}$ \\
\hline & $\mathrm{C} 2$ & 0.00 & 39.41 & 2.73 & 77.40 & 138.22 & 179.25 & 234.03 & 242.45 & 399.80 & 295.11 & 390.23 & ND & 235.24 & ND & $\mathrm{N}$ \\
\hline & $\mathrm{C} 3$ & 0.00 & 38.76 & ND & 77.66 & 139.05 & 177.84 & 243.72 & 249.01 & 402.08 & 301.25 & 383.14 & ND & 237.29 & ND & $\mathrm{N}$ \\
\hline & $\mathrm{C} 4$ & 0.00 & 27.24 & 1.45 & 55.67 & 106.26 & 118.00 & 177.71 & 174.67 & 272.19 & 209.09 & 273.82 & ND & ND & ND & $\mathrm{N}$ \\
\hline & C5 & 0.00 & 26.80 & 0.68 & 55.12 & 106.58 & 122.71 & 174.78 & 173.25 & 272.95 & 207.19 & ND & ND & 154.25 & ND & $\mathrm{N}$ \\
\hline & $\mathrm{C} 6$ & 0.00 & 38.97 & 1.61 & 79.44 & 145.34 & 178.66 & 245.42 & 247.66 & 403.89 & 304.31 & 387.51 & 463.70 & ND & ND & $\mathrm{N}$ \\
\hline & $\mathrm{C7}$ & 0.00 & 25.92 & 0.00 & 52.16 & 93.48 & 120.74 & 157.06 & 160.91 & 266.33 & 198.53 & ND & 306.35 & ND & ND & $\mathrm{N}$ \\
\hline & $\mathrm{C} 8$ & 0.00 & 26.68 & 0.00 & 54.67 & 96.57 & 158.51 & 178.52 & 174.56 & 272.23 & 210.04 & 285.00 & 309.99 & 156.51 & ND & $\mathrm{N}$ \\
\hline & $\mathrm{C9}$ & 0.00 & ND & 0.03 & 77.18 & 138.89 & 184.07 & 239.46 & 248.21 & 406.00 & 299.65 & ND & ND & 233.75 & ND & $\mathrm{N}$ \\
\hline & C10 & 69.74 & 28.90 & 1.37 & 56.58 & 103.12 & 130.86 & 177.26 & 176.21 & 274.86 & 210.62 & 267.49 & ND & ND & ND & $\mathrm{N}$ \\
\hline \multirow[t]{11}{*}{ ETA } & E1 & 0.00 & 26.30 & 6.54 & 54.13 & 98.60 & 187.68 & 181.79 & 176.67 & 276.72 & 211.70 & 277.20 & 309.48 & 164.10 & ND & $\mathrm{N}$ \\
\hline & E2 & 0.00 & 25.99 & ND & 53.58 & 103.32 & 176.03 & 186.92 & 180.44 & 276.39 & ND & 272.36 & ND & 156.58 & ND & $\mathrm{N}$ \\
\hline & E3 & 0.05 & 26.08 & ND & 53.91 & 100.17 & 151.70 & 188.31 & 189.15 & 277.62 & 198.29 & 260.77 & 304.49 & 175.86 & ND & $\mathrm{N}$ \\
\hline & E4 & 0.00 & 26.29 & 2.18 & 56.59 & 107.06 & 184.51 & 185.69 & 179.53 & 274.74 & 203.58 & 270.34 & 313.25 & 160.22 & ND & $\mathrm{N}$ \\
\hline & E5 & 0.00 & 27.78 & 0.07 & 64.55 & 147.87 & 218.04 & 205.36 & 200.14 & 289.71 & 227.57 & 318.54 & 310.26 & 176.81 & ND & 6 \\
\hline & E6 & 0.00 & 27.07 & ND & 55.47 & 102.11 & 142.38 & 170.14 & 167.73 & 271.69 & 191.22 & 263.80 & ND & ND & ND & $\mathrm{N}$ \\
\hline & E7 & 10.98 & 32.81 & 5.17 & 65.62 & 140.49 & 174.12 & 247.72 & 239.08 & 314.24 & 264.44 & 345.82 & 302.68 & 262.66 & 549.66 & 6 \\
\hline & E8 & 0.00 & 40.86 & 1.82 & 85.31 & 163.16 & 245.64 & 266.84 & 264.57 & 413.63 & 306.67 & 396.91 & 452.88 & 259.32 & ND & $\mathrm{N}$ \\
\hline & E9 & 48.99 & 31.02 & 3.14 & 69.25 & 175.53 & 222.23 & 289.06 & 255.16 & 305.16 & 277.12 & 307.12 & 320.41 & 197.01 & ND & $\mathrm{N}$ \\
\hline & E10 & 0.00 & 25.66 & ND & 52.95 & 94.61 & 161.53 & 160.26 & 165.29 & 269.71 & 199.09 & 259.89 & 309.53 & ND & ND & $\mathrm{N}$ \\
\hline & E11 & 0.00 & 26.38 & ND & 52.61 & 93.90 & 145.41 & 176.78 & 173.06 & 273.78 & 198.93 & 281.31 & 315.80 & 158.90 & ND & $\mathrm{N}$ \\
\hline \multirow[t]{6}{*}{ GB } & $\mathrm{G} 1$ & 0.32 & 26.09 & 0.00 & 50.90 & 94.20 & 122.31 & 164.99 & 167.56 & 272.23 & 191.65 & 262.08 & ND & 158.39 & ND & $\mathrm{N}$ \\
\hline & G2 & 0.00 & 25.67 & 0.00 & 53.28 & 117.15 & 125.16 & 183.29 & 181.58 & 276.82 & 209.93 & 270.96 & 305.16 & 157.18 & ND & $\mathrm{N}$ \\
\hline & G3 & 25.74 & 27.63 & 3.69 & 57.67 & 115.80 & 128.13 & 221.14 & 207.84 & 288.55 & 233.93 & 300.87 & 314.77 & 169.85 & ND & $\mathrm{N}$ \\
\hline & G4 & 11.38 & 41.99 & 2.67 & 81.26 & 152.52 & 189.97 & 299.67 & 292.49 & 427.29 & 334.47 & 418.40 & 456.97 & 238.74 & ND & $\mathrm{N}$ \\
\hline & G5 & 0.00 & 25.88 & 0.86 & 53.46 & 106.83 & 123.81 & 165.50 & 166.17 & 269.50 & 200.80 & 270.20 & ND & 155.49 & ND & $\mathrm{N}$ \\
\hline & G6 & 0.00 & 38.60 & ND & 75.82 & 131.65 & 178.14 & 225.79 & 234.44 & 399.03 & 287.63 & 388.18 & ND & 230.13 & ND & $\mathrm{N}$ \\
\hline \multirow[t]{6}{*}{ MB } & M1 & 42.47 & ND & 2.56 & 80.96 & 144.62 & 182.77 & 249.23 & 251.49 & 406.63 & 306.66 & 404.14 & 444.51 & 252.18 & ND & 6 \\
\hline & M2 & 71.41 & ND & 2.30 & 60.05 & 121.38 & 142.02 & 203.12 & 195.60 & 283.51 & 214.22 & ND & 319.36 & 162.39 & ND & $\mathrm{N}$ \\
\hline & M3 & 69.78 & 31.20 & 4.67 & 64.22 & 187.56 & 156.75 & 365.56 & 335.70 & 375.83 & 324.39 & 328.47 & 338.64 & 257.65 & 550.53 & $\mathrm{~N}$ \\
\hline & M4 & 21.42 & 25.88 & 5.06 & 56.74 & 109.32 & 124.29 & 159.73 & 164.31 & 269.94 & 199.14 & 257.21 & 302.91 & 153.66 & ND & $\mathrm{N}$ \\
\hline & M5 & 7.27 & 41.05 & 0.16 & 81.07 & 149.12 & 184.10 & 263.18 & 270.94 & 416.91 & 312.56 & ND & ND & ND & ND & $\mathrm{N}$ \\
\hline & M6 & 0.00 & 38.53 & 4.15 & 78.29 & 139.17 & 177.86 & 240.92 & 251.80 & 410.17 & 299.46 & ND & 451.71 & 242.09 & ND & $\mathrm{N}$ \\
\hline
\end{tabular}

Note: ND expresses the sample concentration below the detection limit; LC, ETA, GB, MB, STA, WTA, and ZB represents the different lake areas i.e., Lake Cente Bay, Meiliang Bay, South Taihu area, West Taihu area and Zhushan Bay, respectively.

In the past 5 years, related researches on the average concentrations of $\sum_{16} \mathrm{PAHs}$ worldwide had been aggregated in this study (Fig. 2). Many studies compa $\sum_{16} \mathrm{PAHs}$ in the surface sediments in China ${ }^{25,27-29}$. The values of $\sum_{16} \mathrm{PAHs}$ in Mediterranean Ports ${ }^{30}$, Maba River ${ }^{31}$, Indian Sundarbans ${ }^{32}$, Forcados Rivers, $\mathrm{c}$ higher than $10000 \mathrm{ng} \mathrm{g}^{-1}$. It was worth pointing out that average values in the sediments from Douro River estuary and Porto Atlantic coast (Portugal) were a which could induce aquatic metabolism disorders and promote unpredictable effects on humans healthy. The concentration of $\sum_{16}$ PAHs in Taihu Lake was this study. 


\begin{tabular}{|c|c|c|c|c|c|c|c|c|c|c|c|c|c|c|c|c|}
\hline \multicolumn{2}{|c|}{$\begin{array}{l}\text { Sample } \\
\text { points }\end{array}$} & \multirow{2}{*}{$\begin{array}{l}\text { Nap } \\
49.39\end{array}$} & \multirow{2}{*}{$\begin{array}{l}\text { Acy } \\
29.59\end{array}$} & \multirow{2}{*}{$\begin{array}{l}\text { Ace } \\
4.15\end{array}$} & \multirow{2}{*}{\begin{tabular}{|l|} 
Flu \\
64.29
\end{tabular}} & \multirow{2}{*}{$\begin{array}{l}\text { Phe } \\
144.29\end{array}$} & \multirow{2}{*}{$\begin{array}{l}\text { Ant } \\
142.51\end{array}$} & \multirow{2}{*}{\begin{tabular}{|l|} 
Flua \\
236.37
\end{tabular}} & \multirow{2}{*}{\begin{tabular}{|l|} 
Pyr \\
223.03
\end{tabular}} & \multirow{2}{*}{\begin{tabular}{|l|} 
BaA \\
302.92
\end{tabular}} & \multirow{2}{*}{$\begin{array}{l}\text { Chry } \\
242.52\end{array}$} & \multirow{2}{*}{$\begin{array}{l}\mathrm{BbF} \\
317.38\end{array}$} & \multirow{2}{*}{$\begin{array}{l}\text { BkF } \\
308.15\end{array}$} & \multirow{2}{*}{\begin{tabular}{|l|}
$\mathrm{BaP}$ \\
183.74
\end{tabular}} & \multirow{2}{*}{$\begin{array}{l}\text { DahA } \\
\text { ND }\end{array}$} & \multirow[t]{2}{*}{ Ic } \\
\hline & M7 & & & & & & & & & & & & & & & \\
\hline & M8 & 0.00 & 38.85 & ND & 78.67 & 156.97 & 186.38 & 299.80 & 298.40 & 437.93 & 332.15 & 443.84 & 468.33 & 250.84 & ND & $\mathrm{N}$ \\
\hline & M9 & 0.00 & 26.85 & 1.54 & 57.54 & 114.45 & 134.38 & 204.27 & 200.42 & 288.68 & 226.21 & 280.05 & 314.10 & 165.31 & ND & $\mathrm{N}$ \\
\hline & M10 & 16.19 & 26.60 & ND & 54.53 & 02.36 & 127.17 & 177.27 & 174.80 & 274.88 & 205.07 & 262.19 & ND & ND & ND & $\mathrm{N}$ \\
\hline & M11 & 0.00 & 38.92 & 8.44 & 77.20 & 136.29 & 181.26 & 242.95 & 247.37 & 406.50 & 299.80 & ND & 448.16 & ND & ND & $\mathrm{N}$ \\
\hline \multirow[t]{4}{*}{ STA } & S1 & 0.00 & 27.28 & 3.40 & 53.30 & 97.36 & 163.02 & 167.68 & 169.49 & 270.00 & 205.80 & 264.17 & 306.54 & ND & ND & $\mathrm{N}$ \\
\hline & S2 & 0.00 & 38.75 & 0.00 & 76.53 & 143.56 & 177.52 & 252.47 & 259.07 & 409.71 & 305.27 & 426.65 & ND & ND & ND & $\mathrm{N}$ \\
\hline & S3 & 18.90 & 38.44 & 2.21 & 76.53 & 138.35 & 176.07 & 232.58 & 241.23 & 399.27 & 294.42 & ND & ND & 233.03 & ND & 6 \\
\hline & S4 & 63.37 & 27.67 & 5.62 & 60.96 & 121.27 & 124.51 & 182.80 & 180.50 & 273.57 & 216.96 & 282.45 & 304.02 & 154.90 & ND & $\mathrm{N}$ \\
\hline \multirow[t]{4}{*}{ WTA } & W1 & 78.15 & ND & 6.57 & 65.42 & 146.75 & 141.95 & 248.17 & 234.96 & 305.03 & 24 & $2 \varepsilon$ & 3 & - & ND & $\mathrm{N}$ \\
\hline & W2 & 0.00 & 29.14 & 4.23 & 62.77 & 133.21 & 152.42 & 209.60 & 210.30 & 290.97 & 224.43 & 289.1 & 308.1 & 19 & ND & $\mathrm{N}$ \\
\hline & W3 & 49.50 & 27.76 & 1.95 & 58.77 & 110.91 & 123.05 & 174.66 & 168.76 & 272.97 & 186.93 & 285.68 & 301.34 & - & ND & $\mathrm{N}$ \\
\hline & W4 & 31.27 & 25.72 & 3.20 & 62.90 & 114.37 & 130.26 & 174.95 & 177.06 & 274.52 & 206.78 & ND & ND & - & ND & $\mathrm{N}$ \\
\hline \multirow[t]{6}{*}{ ZB } & Z1 & 63.10 & 28.98 & 5.23 & 63.38 & 135.29 & 146.74 & 198.30 & 198.06 & 285.57 & 220.16 & 276.24 & ND & 183.60 & ND & 7 \\
\hline & Z2 & 41.89 & 42.18 & 0.00 & 93.48 & 184.75 & 204.60 & 280.61 & 289.34 & 419.03 & 317.72 & 412.27 & 463.39 & 240.43 & ND & $\mathrm{N}$ \\
\hline & Z3 & 94.80 & 32.33 & 9.95 & 68.93 & 182.79 & 171.18 & 293.40 & 286.80 & 328.45 & 289.14 & 283.37 & 329.59 & 194.13 & 551.50 & 9 \\
\hline & Z4 & 44.42 & 46.39 & 6.40 & 92.44 & 212.31 & 237.40 & 328.17 & 349.91 & 439.20 & 355.34 & ND & 448.49 & 298.08 & ND & $\mathrm{N}$ \\
\hline & Z5 & 38.96 & 30.18 & 4.00 & 68.39 & 143.42 & 164.95 & 325.77 & 322.39 & 416.24 & 387.20 & 503.08 & 415.11 & 360.92 & ND & $\mathrm{N}$ \\
\hline & Z6 & 1.35 & 41.34 & 0.00 & 83.01 & .48 & 212.66 & 281.45 & 285.59 & 426.33 & 331.13 & 406.85 & 476.68 & 259.13 & ND & $\mathrm{N}$ \\
\hline
\end{tabular}

Note: ND expresses the sample concentration below the detection limit; LC, ETA, GB, MB, STA, WTA, and ZB represents the different lake areas i.e., Lake Cente Bay, Meiliang Bay, South Taihu area, West Taihu area and Zhushan Bay, respectively.

In the past 5 years, related researches on the average concentrations of $\sum_{16} \mathrm{PAHs}$ worldwide had been aggregated in this study (Fig. 2). Many studies compa $\sum_{16} \mathrm{PAHs}$ in the surface sediments in China ${ }^{25,27-29}$. The values of $\sum_{16} \mathrm{PAHs}$ in Mediterranean Ports ${ }^{30}$, Maba River ${ }^{31}$, Indian Sundarbans ${ }^{32}$, Forcados Rivers, $\mathrm{c}$ higher than $10000 \mathrm{ng} \mathrm{g}^{-1}$. It was worth pointing out that average values in the sediments from Douro River estuary and Porto Atlantic coast (Portugal) were a which could induce aquatic metabolism disorders and promote unpredictable effects on humans healthy. The concentration of $\sum_{16}$ PAHs in Taihu Lake was : this study.

\section{Occurrence and compositions of PAHs in different lake areas}

The values of $\sum_{16} \mathrm{PAHs}$ in different regions were calculated, and the proportions of different monomers of PAHs were analyzed. Figure 3 showed that the concentration of $\sum_{16} \mathrm{PAHs}$ in the ZB lake area was much higher than in the other regions, and the same research results have appeared many times in previous studies ${ }^{35,36}$. The sources of agricultural, industrial, and domestic sewage in the surrounding watershed of ZB were higher than the other locations ${ }^{37}$, resulting in higher PAHs concentrations than other areas. The concentration in the north of Taihu Lake was higher than that in the south, and the surrounding concentration was higher than the central region, which mainly depended on the anthropogenic activities, i.e., industrial and agricultural development around the area ${ }^{38}$. The 4-ring PAHs were dominant, accounting for 35.69\% 45.02\%. A previous Suzhou Industrial Park study pointed out that medium-molecularweight PAHs (4-ring) were predominant in stream sediments ${ }^{39}$, but in this study, the top 4 regions with higher average PAHs concentrations (ZB, MB, ETA, WTA) showed high-molecular-weight PAHs (5 6-ring) were dominant. The low-molecular-weight (2 3-ring) PAHs were mainly derived from the release and combustion of petroleum emissions, and medium to high-molecular-weight (4 6 rings) PAHs were mainly derived from pyrolysis ${ }^{40}$, of which 5 and 6 rings were sources from anthropogenic pyrolysis ${ }^{41,42}$, which preliminarily proved the main source of the study area in Taihu La

\section{Source appointment of PAHs in the sediments and influencing factors}

The sources of PAHs could be identified based on the molecular diagnostic ratio of PAH in the samples ${ }^{43,44}$. The proportion of PAH monomer was calculated in this study (Fig. 4). The ratios of Ant/(Ant+Phe) in most sediment samples from Lake Taihu were greater than 0.10, while in ZB was less than 0.10. The same phenomenon appeared in the $\mathrm{BaA} /(\mathrm{BaA}+\mathrm{Chr})$ ratios, in addition to $\mathrm{ZB}$, ratios were greater than 0.35 , indicating that except for $\mathrm{ZB}$, where was the petroleum source, the main sources of PAHs in other regions from Taihu Lake were combustion. The values of Flua/(Flua+Pyr) were mainly greater than 0.50 , and the values of LC and STA were between 0.40 and 0.50, which represented the PAHs in LC and STA came from liquid fossil fuels (vehicles and crude oil). IcdP/(IcdP+BghiP) of ETA and WTA between 0.20 and 0.50 , which meant the burning of liquid fossil fuels ${ }^{43,45}$. Based on the above results, it was further derived the PAHs in ZB mainly were the petroleum source, the main sources of GB and MB were the burning of grass, wood and coal, while PAHs in other areas of Taihu Lake were the combustion of liquid fossil fuels, which was consistent with the previous studies ${ }^{46,47}$. 
To further determine the source of PAHs, PCA was selected as an effective identification tool. Figure 5 illustrated the score plot of the first two components (PC) of PAHs in surface sediments of Taihu Lake, accounting for $96.8 \%$ of the variance. $\mathrm{PC}_{1}$ was responsible for $92.5 \%$ of the total variance and exhibited high loading for BghiP, BaA, BbF, Chry, BkF, Flua, and Pyr (4.43, 3.85, 2.30, 2.06, 1.66, 1.41, and 1.40). $\mathrm{PC}_{2}$ was responsible for $4.3 \%$ of the total variance, and mostly due to IcdP, BghiP, and DahA (1.56, 0.47, and 0.15). It has been proved in previous studies, BghiP, BkF, and IcdP were derived from vehicle exhaust, BaA and Chry were the products of petroleum combustion, BbF was a product of the high-temperature combustion, and Flua and Pyr came from coal-burning ${ }^{48-50}$. To further derive, the main sources of PAHs in the surface sediments from Taihu Lake were the man-made sources, including vehicle exhaust and combustion, which was consistent with the results of PAH molecular diagnostic ratio.

\section{Risk assessment and ecological suggestions}

The biological toxicity assessment of PAHs in different sediments from Taihu Lake was compared. It was shown (Table 2) that the concentrations of Nap, Ace, Phe, Flua, Pyr, and BaP in all sampling sites were lower than those of ERL value, which would not cause adverse effects on the environment. The concentrations of Chry, BkF, BbF, and BghiP at some sampling points were higher than ERL value but lower than ERM value, which had little impact on the environment, which was the same as Acy, Flu, Ant, BaA. It was worth noting that both DahA and IcdP were much higher than ERM values, influencing greatly on the ecological community.

Table 2

The biological toxicity assessment form of PAHs in different sediments of Taihu Lake $\left(\mathrm{ng} \mathrm{g}^{-1} \mathrm{dw}\right)$

\begin{tabular}{|c|c|c|c|c|c|c|c|c|c|c|}
\hline \multirow[t]{2}{*}{ PAHs } & \multirow[t]{2}{*}{ ERL } & \multirow[t]{2}{*}{ ERM } & \multicolumn{7}{|c|}{ Average concentration in different lake areas } & \multirow[t]{2}{*}{ Concentration range } \\
\hline & & & ZB & MB & GB & ETA & STA & WTA & LC & \\
\hline Nap & 160.00 & 2100.00 & 47.42 & 25.27 & 6.24 & 5.46 & 20.57 & 39.73 & 7.87 & $0.00 \sim 94.80$ \\
\hline Acy & 16.00 & 500.00 & 36.90 & 27.04 & 30.98 & 28.75 & 33.04 & 20.66 & 27.88 & NA 46.39 \\
\hline Ace & 44.00 & 640.00 & 4.26 & 3.00 & 1.20 & 1.72 & 2.80 & 3.99 & 1.49 & NA 9.95 \\
\hline Flu & 19.00 & 540.00 & 78.27 & 68.51 & 62.07 & 60.36 & 66.83 & 62.47 & 63.95 & $50.90 \sim 93.48$ \\
\hline Phe & 240.00 & 1500.00 & 169.67 & 136.87 & 119.69 & 120.62 & 125.14 & 126.31 & 116.77 & $93.48 \sim 212.31$ \\
\hline Ant & 85.30 & 1100.00 & 189.59 & 158.14 & 144.59 & 182.66 & 160.28 & 136.92 & 149.16 & $118.00 \sim 245.64$ \\
\hline Flua & 600.00 & 5100.00 & 284.62 & 240.21 & 210.06 & 205.35 & 208.88 & 201.85 & 199.99 & $157.06 \sim 365.56$ \\
\hline Pyr & 665.00 & 2500.00 & 288.68 & 237.62 & 208.35 & 199.17 & 212.57 & 197.99 & 202.12 & $160.91 \sim 349.91$ \\
\hline $\mathrm{BaA}$ & 261.00 & 1600.00 & 385.80 & 352.17 & 322.24 & 294.85 & 338.14 & 285.87 & 324.16 & $266.33 \sim 439.20$ \\
\hline Chry & 384.00 & 2800.00 & 316.78 & 269.29 & 243.06 & 207.15 & 255.61 & 216.42 & 244.43 & NA 387.20 \\
\hline $\mathrm{BkF}$ & 280.00 & 1620.00 & 355.54 & 308.72 & 179.48 & 267.16 & 152.64 & 233.92 & 139.36 & NA 503.08 \\
\hline $\mathrm{BbF}$ & 320.00 & 1880.00 & 313.63 & 208.48 & 318.45 & 295.82 & 243.31 & 216.14 & 225.91 & NA 476.68 \\
\hline $\mathrm{BaP}$ & 430.00 & 1600.00 & 256.05 & 151.62 & 184.96 & 155.59 & 96.98 & 49.85 & 117.86 & $\mathrm{NA} \sim 360.92$ \\
\hline DahA & 63.40 & 260.00 & 91.92 & 50.05 & NA & 19.97 & NA & NA & NA & NA 551.50 \\
\hline IcdP & - & - & 269.28 & 56.60 & NA & 117.72 & NA & 155.32 & NA & NA 913.86 \\
\hline BghiP & 430.00 & 1600.00 & 444.85 & 348.05 & 297.97 & 347.68 & 338.07 & 408.85 & 304.70 & $\mathrm{NA} \sim 615.11$ \\
\hline
\end{tabular}

Note: ZB, MB, ETA, WTA, GB, STA, and LC represent the Zhushan Bay, Meiliang Bay, East Taihu area, West Taihu area Gonghu Bay, South Taihu area, and Lake Center, respectively.

Due to the high carcinogenicity of DahA and IcdP ${ }^{51,52}$, the carcinogenic risk of DahA and IcdP had been further studied in this study. The BaPE was a useful indicator for quantitative assess the potential carcinogenic risks of $\mathrm{PAHs} \mathrm{s}^{53,54}$.

The BaPE in this study was calculated through the data of Table 1, and the calculation results were shown in Fig. 6 . It could be seen from Fig. 6 that BaPE values for 52 surface sediments samples of Taihu Lake varied from 16.47 to $708.62 \mathrm{ng} \mathrm{g}^{-1} \mathrm{dw}$. The high BaPE levels were noticed at sites E7, M3, Z3, and Z5 indicating that PAHs in these sites showed relatively high toxicity compared to other sites. The PAHs in ZB, MB, and southeast area of Taihu Lake had higher carcinogenic risks, compared with 2012, the risk of PAHs had increased obviously ${ }^{37}$.

\section{Conclusions}

In this work, 16 priority PAHs in spatial sediments from Taihu Lake, China were compared, and the possible new input contributions were estimated. The current pollution levels of PAHs in different lake areas were at a medium-to-high global level with an increasing dominant high-ring PAHs. The distributions of $\mathrm{PAHs}$ around the basin were higher than those in the central areas of the lake indicating the high frequency of anthropogenic activities, high economic and development levels in the lake area. The high population density in the study area presented a more comprehensive view to evaluate the regional impact on PAHs sources. PAHs in Zhushan Bay were mainly sourced from petroleum, however, the main origins of PAHs in both Gonghu Bay and Meiliang Bay were derived from the burning of grass, wood, and coal. For other lake areas, the combustion of liquid fossil fuels contributed greatly. ERL and ERM values 
combining BaPE values with the difference of lake areas were calculated to evaluate regional impact more comprehensively, which was different from previous results that grass-type lake zones may not necessarily present high regional impacts. PAHs in Zhushan Bay, Meiliang Bay, and the southeast of Taihu Lake had a high risk of carcinogenesis and showed an upward trend year by year.

\section{Declarations}

\section{Acknowledgements}

This work was supported by the National Natural Science Foundation of China (No. 41673107) and the Major Project of Jiangsu Provincial Department of Education (No. 20KJA170001)

\section{Author contributions}

Xiulu Lang wrote the original draft; Xinghua He and Tian Sun drew the pictures involved in the article; Yanhua Wang conceived and revised the manuscript; $\mathrm{Xi}$ Chen, Zihan Zhao and Mingli Zhang collected the samples. All authors discussed the results. All authors have read and agreed with this manuscript version.

\section{Competing interests}

The authors declare no competing interests.

\section{References}

1. Froehner, S., Rizzi, J., Vieira, L. M. \& Sanez, J. PAHs in water, sediment and biota in an area with port activities. Archives of Environmental Contamination and Toxicology, 75, 236-246 https://doi.org/10.1007/s00244-018-0538-6 (2018).

2. Anyanwu, I. N., Sikoki, F. D. \& Semple, K. T. Risk assessment of PAHs and N-PAH analogues in sediment cores from the Niger Delta. Mar. Pollut. Bull, 161, 111684 https://doi.org/10.1016/j.marpolbul.2020.111684 (2020).

3. Han, B., Cui, D. Y., Liu, A., Li, Q. \& Zheng, L. Distribution, sources, and risk assessment of polycyclic aromatic hydrocarbons (PAHs) in surface sediments from Daya Bay, South China. Environmental Science and Pollution Research, 28, 25858-25865 https://doi.org/10.1007/s11356-020-11956-w (2021).

4. Li, J. W. et al. Polycyclic aromatic hydrocarbons in water, sediment, soil, and plants of the Aojiang River waterway in Wenzhou, China. Journal of Hazardous Materials, 173, 75-81 https://doi.org/10.1016/j.jhazmat.2009.08.050 (2010).

5. Honda, M. \& Suzuki, N. Toxicities of polycyclic aromatic hydrocarbons for aquatic animals. International Journal of Environmental Research and Public Health, 17, 1363 https://doi.org/10.3390/ijerph17041363 (2020).

6. Lu, G. N., Tao, X. Q., Dang, Z., Yi, X. Y. \& Yang, C. Estimation of n-octanol/water partition coefficients of polycyclic aromatic hydrocarbons by quantum chemical descriptors. Central European Journal of Chemistry 6, 310-318 https://doi.org/10.2478/s11532-008-0010-y (2008).

7. Yuan, H. Z., Zhang, E. L., Lin, Q., Wang, R. \& Liu, E. F. Sources appointment and ecological risk assessment of polycyclic aromatic hydrocarbons (PAHs) in sediments of Erhai Lake, a low-latitude and high-altitude lake in southwest China. Environmental Science and Pollution Research, 23, 4430-4441 https://doi.org/10.1007/s11356-015-5626-9 (2016).

8. Souza, M. R. R. et al. Concentration, distribution and source apportionment of polycyclic aromatic hydrocarbons (PAH) in Poxim River sediments, Brazil. Mar. Pollut. Bull, 127, 478-483 https://doi.org/10.1016/j.marpolbul.2017.12.045 (2018).

9. Davis, E. et al. Source apportionment of polycyclic aromatic hydrocarbons (PAHs) in small craft harbor (SCH) surficial sediments in Nova Scotia, Canada. Science of the Total Environment, 691, 528-537 https://doi.org/10.1016/j.scitotenv.2019.07.114 (2019).

10. Dreyer, A., Radke, M., Turunen, J. \& Blodau, C. Long-term change of polycyclic aromatic hydrocarbon deposition to peatlands of eastern Canada. Environmental Science and Technology, 39, 3918-3924 https://doi.org/10.1021/es0481880 (2005).

11. Zhang, Y. X. Polycyclic aromatic hydrocarbons in China: emission, atmospheric transport and lung cancer risk (Beijing University, Beijing, 2010).

12. Zhang, L., Zhu, B., Gao, J. H. \& Kang, H. Q. Impact of Taihu Lake on city ozone in the Yangtze River Delta. Advances in Atmospheric Sciences, 34, 226-234 https://doi.org/10.1007/s00376-016-6099-6 (2017).

13. Huang, S. B., Qiao, M., Wang, H. \& Wang, Z. J. Organchlorinated pesticides in surface sediments of meiliang bay in Taihu Lake, China. Journal of Environmental Science and Health Part a-Toxic/Hazardous Substances and Environmental Engineering, 41, 223-234 https://doi.org/10.1080/10934520500354664 (2006).

14. Su, H. L. et al. Distribution characteristics and risk assessments of PAHs in fish from Lake Taihu, China. Human and Ecological Risk Assessment, 21, 1753-1765 https://doi.org/10.1080/10807039.2014.975003 (2015).

15. Wang, W. W., Qu, X. L., Lin, D. H. \& Yang, K. Octanol-water partition coefficient (logKow) dependent movement and time lagging of polycyclic aromatic hydrocarbons (PAHs) from emission sources to lake sediments: A case study of Taihu Lake, China. Environ. Pollut, 288, 117709 https://doi.org/10.1016/j.envpol.2021.117709 (2021).

16. Peng, X. Z., Zhang, G., Zheng, L. P., Mai, B. X. \& Zeng, S. W. The vertical variations of hydrocarbon pollutants and organochlorine pesticide residues in a sediment core in Lake Taihu, East China. Geochemistry-exploration Environment Analysis, 5, 99-104 https://doi.org/10.1144/1467-7873/03-038 (2005). 
17. Zhang, Y., Lu, Y. \& Zhao, W. Y. Spatial distribution of Polycyclic Aromatic Hydrocarbons from Lake Taihu, China. Bulletin of Environmental Contamination and Toxicology, 87, 80-85 https://doi.org/10.1007/s00128-011-0292-1 (2011).

18. Dong, Y. B. et al. Polycyclic aromatic hydrocarbons in sediments from typical Algae, Macrophyte Lake Bay and adjoining river of Taihu Lake, China: distribution, sources, and risk assessment., 13, 470 https://doi.org/10.3390/w13040470 (2021).

19. Chen, P. \& Liang, J. Polycyclic aromatic hydrocarbons in green space soils in Shanghai: source, distribution, and risk assessment. Journal of Soils and Sediments, 21, 967-977 https://doi.org/10.1007/s11368-020-02838-2 (2021).

20. Xia, Z. et al. New approaches to reduce sample processing times for the determination of polycyclic aromatic compounds in environmental samples., $\mathbf{2 7 4}$, 129738 https://doi.org/10.1016/j.chemosphere.2021.129738 (2021).

21. Sun, T., Wang, Y. H., Tian, J. M. \& Kong, X. G. Characteristics of PAHs in soils under different land-use types and their associated health risks in the northern Taihu Basin, China. Journal of Soils and Sediments, online. https://doi.org/10.1007/s11368-021-03050-6 (2021)

22. Abdollahi, S. et al. Contamination levels and spatial distributions of heavy metals and PAHs in surface sediment of Imam Khomeini Port, Persian Gulf, Iran. Mar. Pollut. Bull, 72, 336-345 https://doi.org/10.1016/j.marpolbul.2013.01.025 (2013).

23. Santos, E. et al. Polycyclic aromatic hydrocarbons (PAH) in superficial water from a tropical estuarine system: Distribution, seasonal variations, sources and ecological risk assessment. Mar. Pollut. Bull, 127, 352-358 https://doi.org/10.1016/j.marpolbul.2017.12.014 (2018).

24. Long, E. R., Field, L. J. \& Macdonald, D. D. Predicting toxicity in marine sediments with numerical sediment quality guidelines. Environmental Toxicology and Chemistry, 17, 714-727 https://doi.org/10.1002/etc.5620170428 (1998).

25. Han, B., Liu, A., He, S., Li, Q. \& Zheng, L. Composition, content, source, and risk assessment of PAHs in intertidal sediment in Shilaoren Bay, Qingdao, China. Mar. Pollut. Bull, 159, 111499 https://doi.org/10.1016/j.marpolbul.2020.111499 (2020).

26. Abba, E. J., Unnikrishnan, S., Kumar, R., Yeole, B. \& Chowdhury, Z. Fine aerosol and PAH carcinogenicity estimation in outdoor environment of Mumbai City, India. International Journal of Environmental Health Research, 22, 134-149 https://doi.org/10.1080/09603123.2011.613112 (2012).

27. Zhang, J. M., Huang, H., Wang, R. J. \& Sun, R. Y. Historical pollution and source contributions of PAHs in sediment cores from the middle reach of Huai River, China. Bulletin of Environmental Contamination and Toxicology, 102, 531-537 https://doi.org/10.1007/s00128-019-02576-3 (2019).

28. Niu, L. X. et al. Field analysis of PAHs in surface sediments of the Pearl River Estuary and their environmental impacts. Environmental Science and Pollution Research, 27, 10925-10938 https://doi.org/10.1007/s11356-020-07689-5 (2020).

29. Han, B., Li, Q., Liu, A., Gong, J. W. \& Zheng, L. Polycyclic aromatic hydrocarbon (PAH) distribution in surface sediments from Yazhou Bay of Sanya, South China, and their source and risk assessment. Mar. Pollut. Bull, 162, 1118000 https://doi.org/10.1016/j.marpolbul.2020.111800 (2021).

30. Vitali, F. et al. Benthic Prokaryotic Community Response to Polycyclic Aromatic Hydrocarbon Chronic Exposure: Importance of Emission Sources in Mediterranean Ports. Frontiers in Marine Science, 6, 590 https://doi.org/10.3389/fmars.2019.00590 (2019).

31. Chen, J. D., Liao, J. B. \& Wei, C. H. Coking wastewater treatment plant as a sources of polycyclic aromatic hydrocarbons (PAHs) in sediments and ecological risk assessment. Sci. Rep, 10, 7833 https://doi.org/10.1038/s41598-020-64835-2 (2020).

32. Balu, S., Bhunia, S., Gachhui, R. \& Mukherjee, J. Assessment of polycyclic aromatic hydrocarbon contamination in the Sundarbans, the world's largest tidal mangrove forest and indigenous microbial mixed biofilm-based removal of the contaminants. Environ. Pollut, 266, 115270 https://doi.org/10.1016/j.envpol.2020.115270 (2020).

33. Iwegbue, C. M. A. et al. Polycyclic aromatic hydrocarbons (PAHs) in surficial sediments from selected rivers in the western Niger Delta of Nigeria: Spatial distribution, sources, and ecological and human health risks. Mar. Pollut. Bull, 167, 112351 https://doi.org/10.1016/j.marpolbul.2021.112351 (2021).

34. Rocha, M. J., Dores-Sousa, J. L., Cruzeiro, C. \& Rocha, E. PAHs in water and surface sediments from Douro River estuary and Porto Atlantic coast (Portugal)-impacts on human health. Environmental Monitoring and Assessment, 189, 425 https://doi.org/10.1007/s10661-017-6137-6 (2017).

35. Lei, P., Zhang, H. \& Shan, B. Q. Vertical records of sedimentary PAHs and their freely dissolved fractions in porewater profiles from the northern bays of Taihu Lake, Eastern China. RSC Advances, 6, 98835-98844 https://doi.org/10.1039/c6ra11180g (2016).

36. Li, A. L. et al. Sedimentary archive of Polycyclic Aromatic Hydrocarbons and perylene sources in the northern part of Taihu Lake, China. Environ. Pollut, 246, 198-206 https://doi.org/10.1016/j.envpol.2018.11.112 (2019).

37. Zhang, Y. et al. Potential source contributions and risk assessment of PAHs in sediments from Taihu Lake, China: Comparison of three receptor models. Water Res, 46, 3065-3073 https://doi.org/10.1016/j.watres.2012.03.006 (2012).

38. Qiao, M., Wang, C. X., Huang, S. B., Wang, D. H. \& Wang, Z. J. Composition, sources, and potential toxicological significance of PAHs in the surface sediments of the Meiliang Bay, Taihu Lake, China. Environ. Int, 32, 28-33 https://doi.org/10.1016/j.envint.2005.04.005 (2016).

39. Yuan, Z. J. et al. Polycyclic aromatic hydrocarbons (PAHs) in urban stream sediments of Suzhou Industrial Park, an emerging eco-industrial park in China: Occurrence, sources and potential risk. Ecotoxicology and Environmental Safety, 214, 112095 https://doi.org/10.1016/10.1016/j.ecoenv.2021.112095 (2021).

40. Yan, W., Chi, J. S., Wang, Z. Y., Huang, W. X. \& Zhang, G. Spatial and temporal distribution of polycyclic aromatic hydrocarbons (PAHs) in sediments from Daya Bay, South China. Environ. Pollut, 157, 1823-1830 https://doi.org/10.1016/j.envpol.2009.01.023 (2009).

41. Arias, A. H. et al. Presence, distribution, and origins of polycyclic aromatic hydrocarbons (PAHs) in sediments from Bahia Blanca estuary, Argentina. Environmental Monitoring and Assessment, 160, 301-314 https://doi.org/10.1007/s10661-008-0696-5 (2010).

42. Yuan, H. Z., Zhang, E. L., Lin, Q., Wang, R. \& Liu, E. F. Sources appointment and ecological risk assessment of polycyclic aromatic hydrocarbons (PAHs) in sediments of Erhai Lake, a low-latitude and high-altitude lake in southwest China. Environmental Science and Pollution Research, 23, 4430-4441 https://doi.org/10.1007/s11356-015-5626-9 (2016). 
43. Yunker, M. B. et al. PAHs in the Fraser River basin: a critical appraisal of PAH ratios as indicators of PAH source and composition. Org. Geochem, 33, 489515 https://doi.org/10.1016/S0146-6380(02)00002-5 (2002).

44. Tobiszewski, M. \& Namiesnik, J. PAH diagnostic ratios for the identification of pollution emission sources. Environ. Pollut, 162, 110-119 https://doi.org/10.1016/j.envpol.2011.10.025 (2012).

45. Zhao, Q., Yu, Q. \& Chen, L. M. Particulate matter and particle-bound polycyclic aromatic hydrocarbons in the Dapu road tunnel in Shanghai. International Journal of Environment and Pollution 41, 21-37 https://doi.org/10.1504/IJEP.2010.032243 (2010).

46. Tian, Y. Z. et al. Source contributions and spatiotemporal characteristics of PAHs in sediments: using three-way source apportionment approach. Environmental Toxicology and Chemistry, 33, 1747-1753 https://doi.org/10.1002/etc.2628 (2014).

47. Zhang, F. et al. Polycyclic aromatic hydrocarbons (PAHs) and $\mathrm{Pb}$ isotopic ratios in a sediment core from Shilianghe Reservoir, eastern China: Implying pollution sources. Appl. Geochem, 66, 140-148 https://doi.org/10.1016/j.apgeochem.2015.12.010 (2016).

48. Harrison, R. M., Smith, D. J. T. \& Luhana, L. Source apportionment of atmospheric polycyclic aromatic hydrocarbons collected from an urban location in Birmingham, U.K.. Environmental Science and Technology 30, 825-832. https://doi.org/10.1021/es950252d (1996)

49. Simcik, M. F., Eisenreich, S. J. \& Lioy, P. J. Source apportionment and source/sink relationships of PAHs in the coastal atmosphere of Chicago and Lake Michigan. Atmos. Environ, 33, 5071-5079 https://doi.org/10.1016/S1352-2310(99)00233-2 (1999).

50. Yang, J., Xu, W. L. \& Cheng, H. Y. Seasonal variations and sources of airborne polycyclic aromatic hydrocarbons (PAHs) in Chengdu, China. Atmosphere, 9 , $63 \mathrm{https} / / /$ doi.org/10.3390/atmos9020063 (2018).

51. Cetin, B. Investigation of PAHs, PCBs and PCNs in soils around a Heavily Industrialized Area in Kocaeli, Turkey: Concentrations, distributions, sources and toxicological effects. Science of the Total Environment, 560, 160-169 https://doi.org/10.1016/j.scitotenv.2016.04.037 (2016).

52. Ali-Taleshi, M. S., Squizzato, S., Riyahi Bakhtiari, A., Moeinaddini, M. \& Masiol, M. Using a hybrid approach to apportion potential source locations contributing to excess cancer risk of $\mathrm{PM}_{2.5}$-bound PAHs during heating and non-heating periods in a megacity in the Middle East. Environmental research, 201, 111617 https://doi.org/10.1016/j.envres.2021.111617 (2021).

53. Xu, J. et al. Historical trends of concentrations, source contributions and toxicities for PAHs in dated sediment cores from five lakes in western China. Science of the Total Environment, 470, 519-526 https://doi.org/10.1016/j.scitotenv.2013.10.022 (2014).

54. Wei, H., Liu, G. B., Yong, T. \& Qin, Z. Emission of polycyclic aromatic hydrocarbons from different types of motor vehicles' exhaust. Environ. Earth Sci, 74, 5557-5564 https://doi.org/10.1007/s12665-015-4570-9 (2015).

\section{Figures}
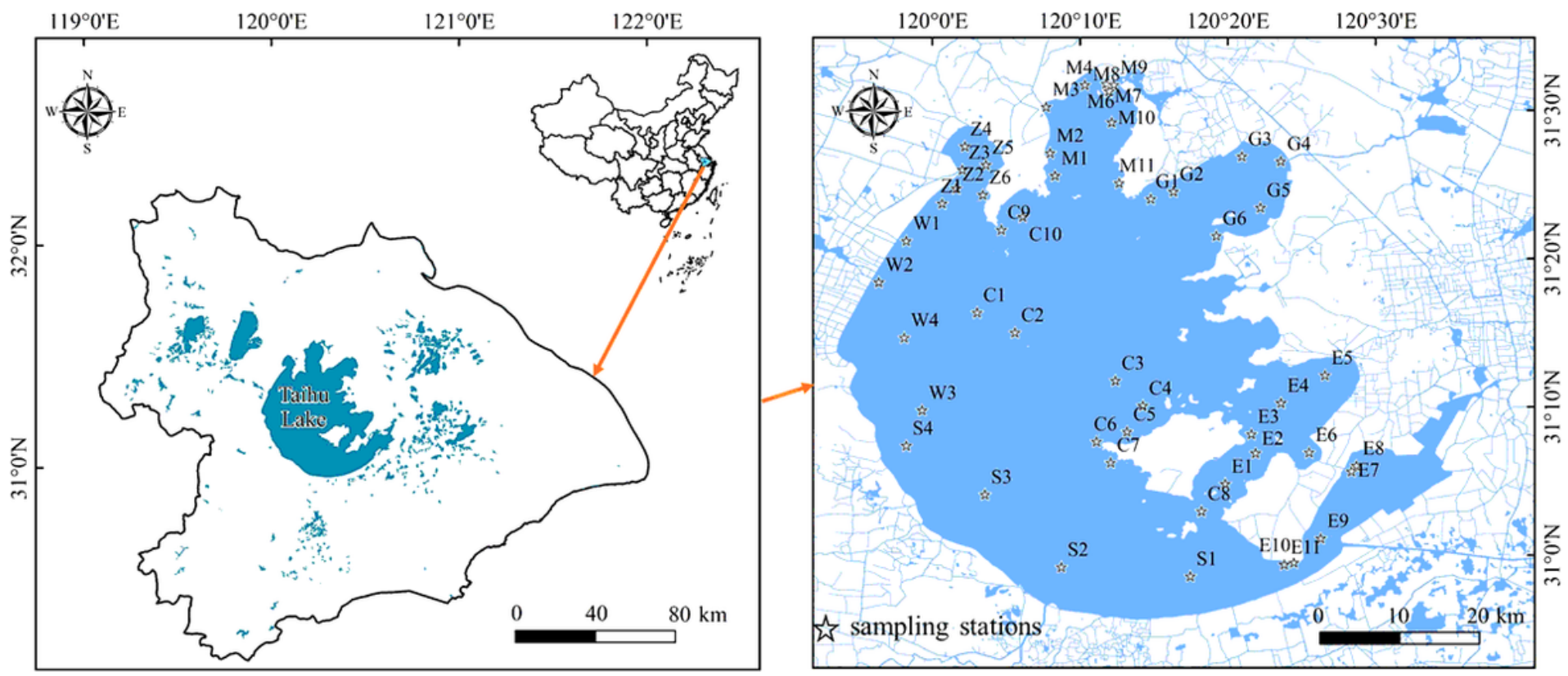

Figure 1

The distributions of specific sampling points 


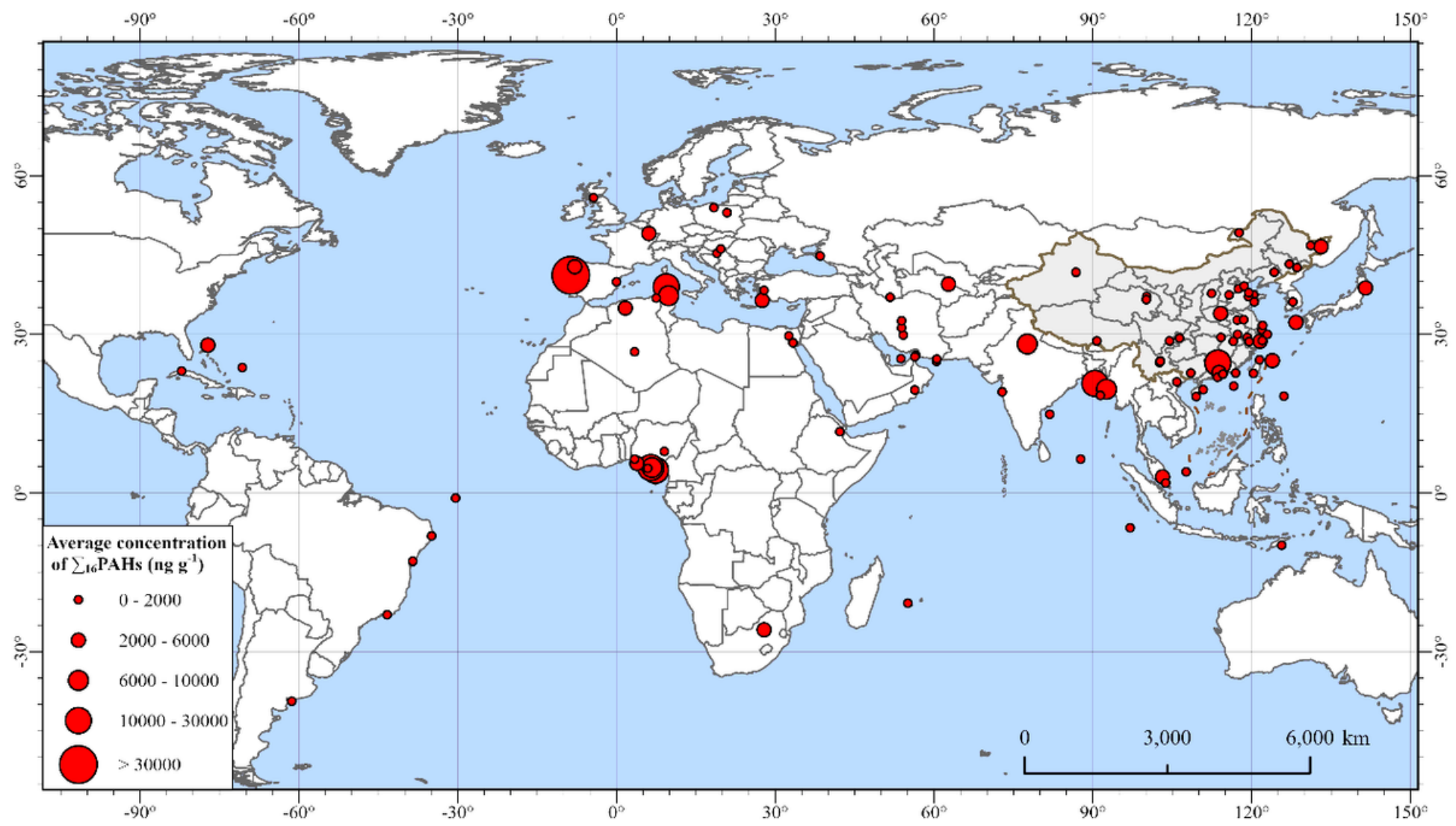

Figure 2

The average concentration of $\sum 16 \mathrm{PAHs}$ worldwide (ng g-1 dw)

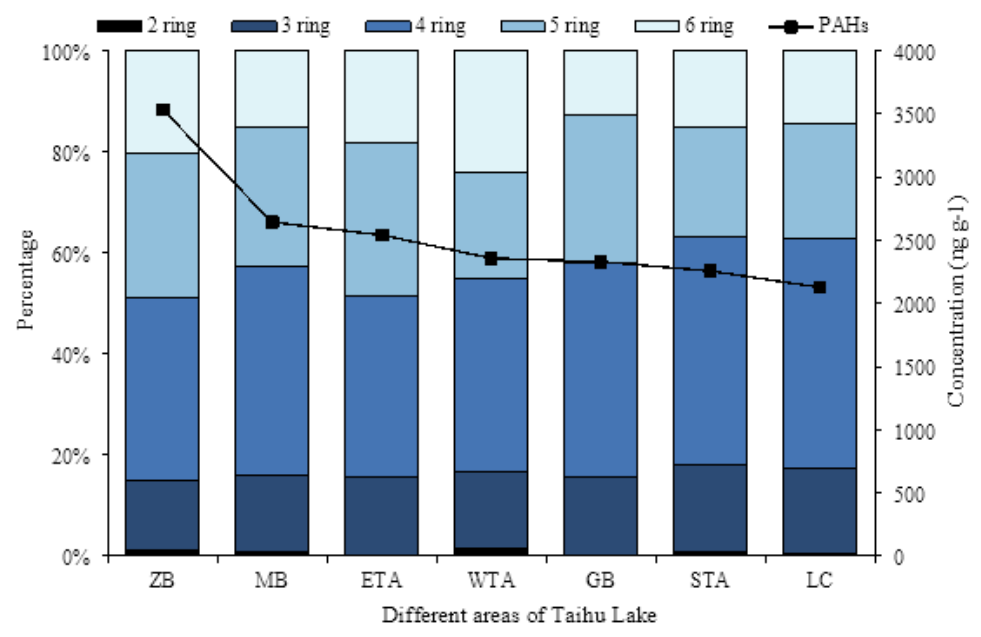

Figure 3

The distribution changes of the PAHs monomers in different lake areas of Taihu Lake 


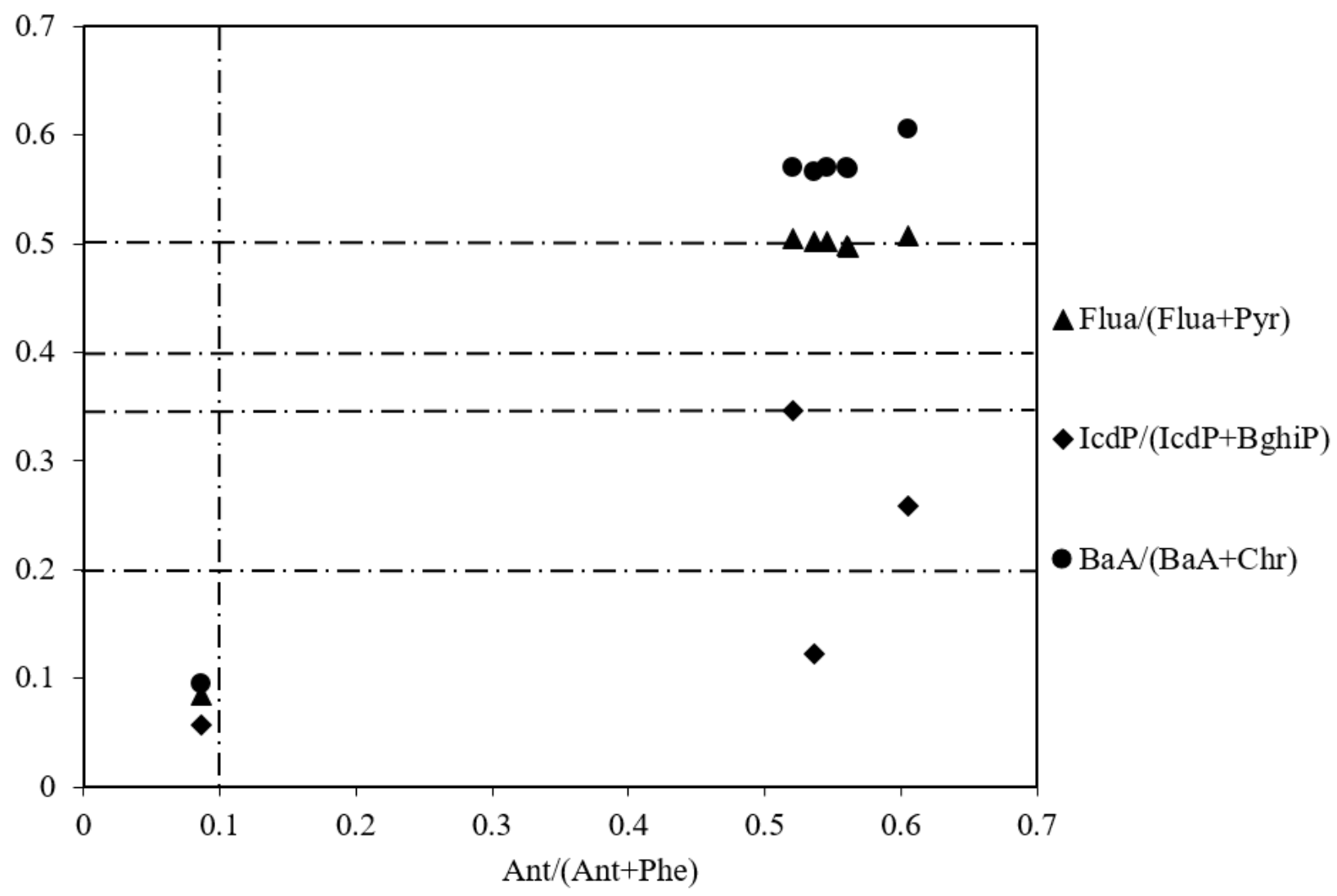

Figure 4

Source apportionment of PAHs in the sediments of Taihu Lake 


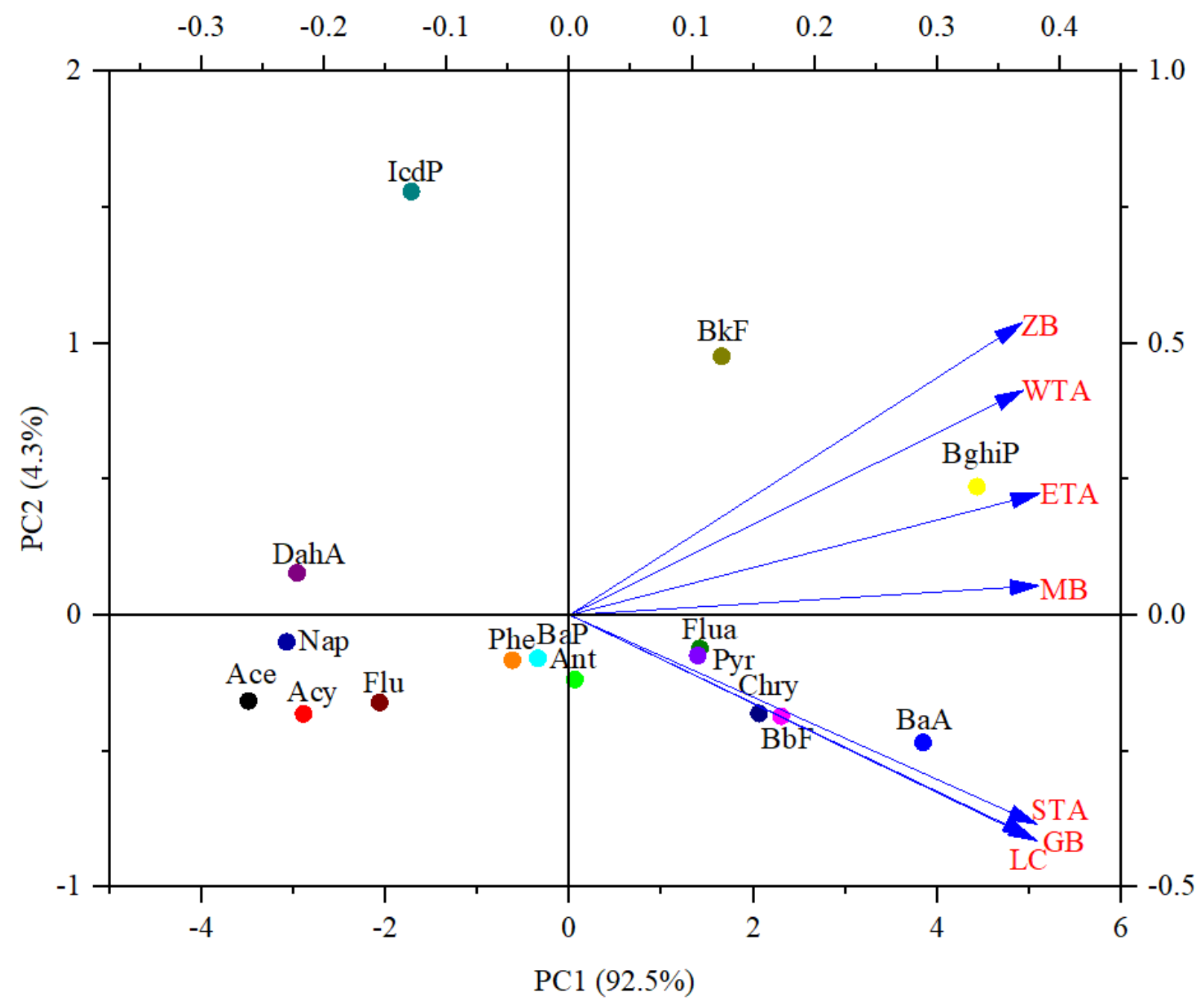

Figure 5

PCA determination of PAHs sources in the sediments of Taihu Lake 


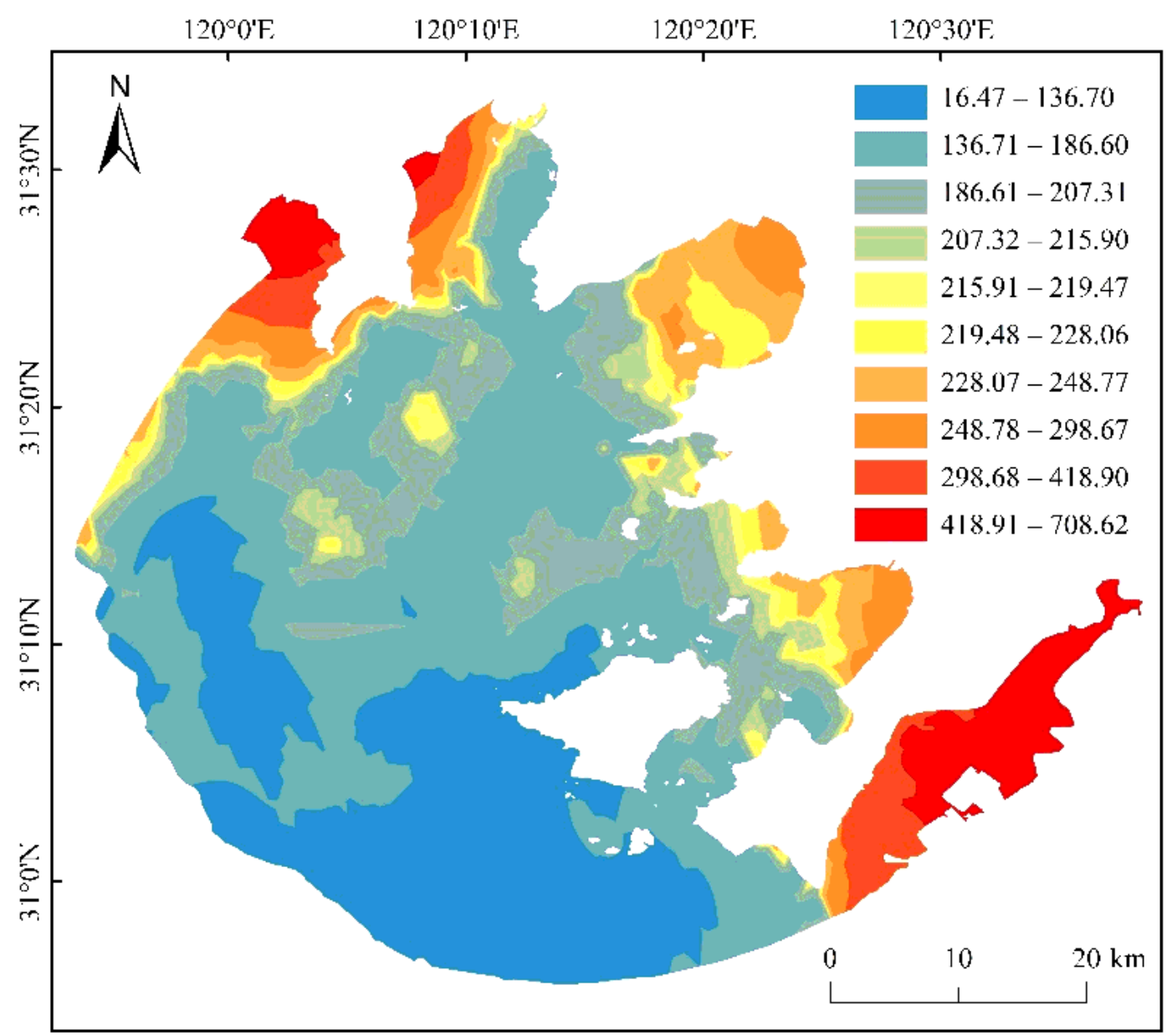

Figure 6

The spatial distribution of BaPE in sediments of Taihu Lake (ng g-1 dw)

\section{Supplementary Files}

This is a list of supplementary files associated with this preprint. Click to download.

- Supplementarymaterials.docx 